\title{
A New Perspective on Poland's Policy towards Russia in 2005-2007: a Middle Power Attempts to Engage a Rising Major Power
}

\author{
MARIJUŠ ANTONOVIČ
}

\section{sciendo}

Politics in Central Europe (ISSN: 1801-3422)

Vol. 17, No. 1

DOI: 10.2478/pce-2021-0001

\begin{abstract}
Scholars of middle powers have been trying to solve its definitional issues and some progress has been made in the systemic approach. This article shows that further advancement may be gained by employing neoclassical realism in studying middle powers' foreign policy behaviour. This done by analysing Poland's policy towards Russia in 2005-2007. It is widely accepted in academic literature that Poland in 2005-2007, during the rule of the Law and Justice Party, pursued a confrontational policy towards Russia. However, this article challenges such widespread views. It demonstrates that Poland's policy towards Russia was actually simultaneously based on balancing and engagement. Using a neoclassical realist framework and data gathered from interviews with Poland's main foreign policymakers at that time, this article shows that the balancing was caused by the power asymmetry and differing interests between Russia and Poland, whereas the engagement - by the Polish policymakers' attempts to influence Russia's intentions towards Poland and by their perceived situation in the European balance of power.
\end{abstract}

Keywords: Polish-Russian relations, Law and Justice Party, Polish foreign policy, Poland's eastern policy, middle powers

\section{Introduction ${ }^{1}$}

International relations (IR) scholars have long argued that it is impossible to apply IR theories towards states in a unified way - there are important differ-

1 The present article is based on a conference paper presented by the author at the Third Annual Tartu Conference on Russian and East European Studies, 11-12 June 2018, Tartu Estonia. 
ences among states in terms of its' territory, geography, capabilities, etc. Hence, states should be categorised by its size and capabilities and IR theories' claims accordingly have to be adjusted. For instance, a lot of work has been done on studying great powers and small states, their foreign policies and adaptations to challenges stemming from the international system.

Among such categorised states are middle powers, though less studied compared to other group of states. There are three ways to describe a middle power. First is identity: those states that claim to be middle powers, should be regarded as one. Second - behaviour. Scholars have identified certain foreign policy attributes which they ascribe to middle powers. If certain country's foreign policy behaviour resembles these attributes, then it can be classified as a middle power. The third way to identify a middle power is by evaluating a country's position in the international system: it should have less capabilities than great powers, but more than small states (Carr 2014, Jordaan 2017). These three approaches can be traced respectively to IR theories of constructivism, liberalism and realism.

However, each approach has it drawbacks. As Andrew Carr (2014: 79) argues the behavioural definition may fall into a tautological trap, whereas Eduard Jordaan (2017: 404) claims that the identity approach still lacks an exterior definition of a middle power. Both agree that the systemic approach cannot predict the behaviour of middle powers (Carr 2014: 72; Jordaan 2017: 404). Though it is still discussed how to rectify these weaknesses, some progress has been achieved on the systemic view. Carr proposes (2014: 79) his "systemic impact" approach, where middle powers are described by having at least some capacity to defend their interest and an ability to initiate or lead change in the international system.

However, this proposal to identify middle powers by their ability to influence the international system is not entirely new. David R. Mares (1988) argued to divide the international system into four categories of states: great powers are those around which balancing occurs, major powers are states that can disrupt, but are unable to change the system unilaterally, middle powers are states that can affect the system together with a few smaller allies, and small powers - states that cannot affect the system, unless in an alliance, which the small power loses any influence on (Mares 1988: 456). It can even be argued that this classification is now a consensus among realists on how to divide states in the international system (Mares 1988; Lobell et al. 2015; Schweller 2017).

Nevertheless, when it comes to predicting middle powers' behaviour, the arguments of realists do not generally differ from their main theoretical claims. For instance, Allan Patience (2014) argues that middle powers usually bandwagon with a great power. Randall L. Schweller (2017) argues that middle powers pursue bandwagoning or balancing policies. Meanwhile, David R. Mares (1988) developed a structural model to find out how middle powers respond to rising powers, which is based on game theory. All in all, the 
majority of authors argue that middle powers either bandwagon or balance against great powers.

Lobell et al. (2015) claim that states may pursue multiple strategies due to participation in different games at different levels, i.e. global, regional and domestic (Lobell et al. 2015: 150-151), but their model does not foresee that states may pursue multiple strategies at the same level even towards the same state. For example, Fareed Zakaria (2020) argues that the USA since the presidency of Richard Nixon until the terms of Barack Obama had been a pursuing a policy of simultaneous engagement and deterrence towards China.

Curiously, one can also find instances when such a strategy was actually implemented by middle powers. Michael Leifer (1999) and Amitav Acharya (1999) have described respectively Indonesia's and Malaysia's attempts to simultaneously balance and engage China at the end of the $20^{\text {th }}$ century. But instances of middle powers pursuing simultaneously engagement and balancing towards a rising power are not found solely in Asia. Another example may be Poland's policy towards Russia in 2000-2014.

This may seem counterintuitive at first glance, as both in the public sphere and in the academic literature, there is widespread belief that Poland solely balanced against Moscow (Lakomy 2001; Cimek et al. 2012; Zaborowski - Longhurst 2007; Zając 2016). But when such views are scrutinised empirically, these arguments appear to be incorrect (Gorska 2010; Kaczmarski - Konończuk 2009: 203-204). What is interesting, this argument even applies to Poland's policy towards Russia in 2005-2007, when the Law and Justice Party (in Polish: Prawo i Sprawiedliwość, PiS) held power. Such a view may seem odd, as many researchers note a deterioration in Polish-Russian relations at that period and usually ascribe it to nationalist attitudes on part of PiS (Kuźniar 2012; Zięba 2013: 182-199; Wawrzyński 2012; Mal'gin 2011: 11-12; Taras 2014; Stolarczyk 2016: 195-206).

Thus, it is possible to identify instances of middle powers pursuing simultaneously engagement and balancing towards a rising power. From a realist point of view this is an anomaly, as it predicts either balancing or bandwagoning is such situations. Hence the goal of this article is to give explanations why middle powers may choose such a policy towards a rising power. It will do so by analysing Poland policy towards Russia in 2005-2007. There are several reasons for choosing this period. First, due to lack of space it is difficult to fully study the period of 2000-2014, when Poland attempted to engage Russia, especially given there were several changes in key foreign policy positions during that period. Second, as mentioned above, there is widespread belief in the academic literature, that Poland pursued an "anti-Russian" policy during that period, so in addition to explaining the reasons behind attempts to engage and balance Russia, this article will also make a claim that these evaluations are false.

Consequently, this article shall contribute to the study of middle powers by providing explanations why it may choose to pursue engagement and balancing 
towards a rising power. Moreover, this study will bring Poland closer to the field of middle power studies. So far, with the exception of Joshua B. Spero (2009), Poland has been marginal in this field. Authors have preferred to study mostly Canada, Australia, South Korea, Turkey, though from a structural approach Poland without doubt can be classified as a middle power. And last but not least, this article will show that neoclassical realism can be a solution to the middle powers structural approach's weakness in predicting states behaviour.

To achieve these objectives this article will use the method of systematic process analysis (Hall 2006) and employ neoclassical realist theory, which sets to find out why states do not follow international systemic imperatives through domestic level variables. Based on this theory, the article shall develop and test four hypotheses. The definition of engagement used in the article is that provided by Evan Resnick (2001: 559). Engagement is a policy of attempting 'to influence the political behaviour of a target state through the comprehensive establishment and enhancement of contacts with that state across multiple-issue areas (i.e. diplomatic, military, economic, or cultural)'The empirical evidence for this article was gathered using a host of primary sources. The main sources of information were interviews with Polish diplomats and politicians that were actively engaged in forming and executing Poland's policy towards Russia in 2005-2007. In total, eight interviews were conducted during 2018-2019, granting the respondents anonymity (for more information about the interviews and the interviewees see the Annex at the end of the article ${ }^{2}$ ). In order to verify claims made in the interviews other primary resources were used, mainly official public and party documents, press releases, politicians' and diplomats' speeches. In addition, secondary sources were utilised: academic, policy, media publications, and memoirs.

\section{Systematic Process Analysis, Neoclassical Realism and Polish-Russian Relations}

\section{Theoretical framework}

This article shall apply the theory of neoclassical realism (Rose 1998; Lobell 2009). It analyses states' foreign policy on two levels. The first is the structural level of the international system. It is based on the theory of neorealism and analyses the position of states in the international system, evaluating how its situation changed in terms of balance of power. The behaviour of individual states is determined by the polarity of the international system, i.e. the number of great powers and their place in the international system, which is based on the military and economic capabilities of the states prevailing at the time (Waltz

\footnotetext{
2 The annex was created according to Bleich - Pekkanen 2013.
} 
1979/2010: 79-128). However, contemporary realists admit that the evaluation of the status of a specific state and the shift in its power is a far more complex issue (Schweller 2003: 332-340) that cannot be reduced solely to military-economic statistics (Barkin 2003: 330). Hence, while analysing the structural level, the focus must be on the threats originating from the international system and radical changes taking place in the system (Lobell 2009: 46-51).

Neoclassical realists also maintain that it is necessary to evaluate the strategic environment in the system, whether it is permissive or restrictive, i.e. to determine the scope and seriousness of any threats and opportunities in the international system. It is also imperative to judge the clarity of signals and information sourced from the international system: how explicit the threats and opportunities in the international system are, whether it is possible to assess the timeframe in which they may materialise, and whether the system provides an unambiguous answer as to which policy would be optimal for the state. And let's not forget the structural modifiers that can also have an impact on the variables mentioned - such as the geography, the rate of technological change, or the offence-defence balance (Ripsman et al. 2016: 33-57).

Unlike realism or neorealism, neoclassical realism argues that states do not solely balance or bandwagon and has identified several other strategies such as buck-passing, chain-ganging, appeasement, hiding (Taliaferro 2006: 469), binding, distancing, and engagement (Schweller 1998: 70-75). In order to explain the selected behaviour strategies of states, it introduces another level of analysis - that of domestic politics of states, which involves scrutiny of how state decision-makers react to imperatives that stem from the international system.

In due course, many potential variables have been applied at this level. As a result, neoclassical realists have received a huge amount of criticism for selecting their variables for domestic politics on an ad hoc basis (Kaarbo 2015: 204; Narizny 2017: 170-171). Norrin M. Ripsmann, Jeffrey W. Taliaferro and Steven E. Lobell tackle this issue in their book on neoclassical realism Neoclassical Realist Theory of International Politics (2016). After having reviewed the main works in neoclassical realist thought, they attempted to group the variables for domestic politics. According to these authors, the stimuli from the international system go through three stages, until they materialise into policy response: perception, decision-making, and policy implementation. These stages are affected by four groups of variables: leader images, strategic culture, state-society relations and domestic institutions (Ripsman et al. 2016).

Each of the groups of the domestic politics variables mentioned earlier comprises discrete variables. Strategic culture is made of organisational culture, society's beliefs, worldviews and expectations, and dominant ideologies. The state - society relations are created by the autonomy of foreign-policy decision-makers from other actors of domestic politics and society's pressures, disagreements between state institutions and society, the dynamics of political coalition 
formation, or the shape of civil-military relations. Domestic institutions are described by formal institutions, organisational and bureaucratic routines and processes, the concentration of power in the hands of foreign policy decision-makers, the relationship between the executive and legislative powers, party systems, the quality of the administration, informal institutions, decision-making procedures, and political practices (Ripsman et al. 2016: 58-79).

The importance of each group of variables is chosen according to the degree of systemic clarity and the nature of strategic environment (Ripsman et al. 2016: 95). This can be shown graphically:

\section{Table 1}

\begin{tabular}{|c|c|c|c|}
\hline & & \multicolumn{2}{|c|}{ Degree of Systemic Clarity (High to Low) } \\
\hline & & High Clarity & Low Clarity \\
\hline \multirow{2}{*}{$\begin{array}{l}\text { Nature of Strategic } \\
\text { Environment } \\
\text { (Restrictive } \\
\text { to Permissive) }\end{array}$} & $\begin{array}{l}\text { Restrictive } \\
\text { Environment }\end{array}$ & $\begin{array}{l}\text { Leader images } \\
\text { and strategic culture }\end{array}$ & $\begin{array}{l}\text { Leader images } \\
\text { and strategic culture }\end{array}$ \\
\hline & $\begin{array}{l}\text { Permissive } \\
\text { Environment }\end{array}$ & $\begin{array}{c}\text { Strategic culture, } \\
\text { Domestic institutions, and } \\
\text { state-society relations }\end{array}$ & $\begin{array}{l}\text { Indeterminate - all four } \\
\text { group of variables } \\
\text { could be relevant }\end{array}$ \\
\hline
\end{tabular}

Source: Ripsman et al. 2016, 95.

The assertion of this article is that Poland during 2005-2007 existed in a permissive environment with relatively high clarity of information (the reasons for that shall be given below). Henceforth, Poland's foreign policy towards Russia is likely to be affected the most by such groups of variables as strategic culture, state-society relations and domestic institutions.

But how can one best select the relevant variables from each of these groups applicable in a given case? Ripsman et al. provide two methods to solve this puzzle. The first one is deductive. On the basis of logical, abstract thinking that relies on earlier theories, theoretical debates, thought experiments and the construction of formal models, the variables that are potentially applicable in a specific case are selected, hypotheses are derived, and conclusions are drawn on how appropriate the model is. In the second - inductive - method, the potentially relevant variables are selected after a superficial acquaintance with the literature on the case. As the authors point out themselves, in practice it is difficult to separate these methods. Each induction has at least an element of deduction and vice versa (Ripsman et al. 2016: 117-118). For this article, variables from each of the potentially influential groups have been selected deductively with an element of induction. Thus, the method used here is based on the recent discussions among neoclassical realists and its applicability to Poland's rela- 
tions with Russia, based on the review of literature on Polish-Russian relations published earlier (Antonovič 2018).

When talking about the state-society relations, it is worth mentioning interest groups. According to neoclassical realists, all essential interest groups such as organised lobby groups, media, public opinion, or parliament - can be treated as one (Ripsman 2009: 171). Since foreign policy decision-makers are interested in preserving their power, interest groups have the biggest influence at the time when foreign policy decision-makers are under threat of losing their power positions (Ripsman 2009: 188). From the above, the first hypothesis may be formed:

Hypothesis 1: Poland tried to improve relations with Russia due to the fact that Polish foreign policy decision-makers were affected by domestic political interest groups.

When discussing the domestic institutions group of variables, one cannot leave out the Polish Constitution, adopted in 1997 and still valid today. According to the Constitution, the task of formulation and execution of Poland's foreign policy falls upon the government. The definition and execution of foreign policy must, however, take place in consultation and negotiation with the president of Poland. ${ }^{3}$ Looking from a neoclassical realist perspective, it can be said that in the regimented institutional structure of Poland's foreign policy, the ability to mobilise resources has been divided, thus creating conditions for a potential conflict among foreign policymakers. Besides, power to mobilise resources may be divided on the governmental level if the government is coalitional. At such points foreign policy may become one of the instruments for discrediting the other side and, in so doing, taking over all the power to mobilise resources for the execution of a desired foreign policy. Hence, another hypothesis can be derived:

Hypothesis 2: Poland's attempt to engage Russia was a consequence of domestic political struggle between competing political actors. This was an attempt to discredit the foreign policies offered by other political groups and in so doing diminish their political influence.

Moving on to the strategic culture group of domestic level variables, this article shall take into account decision-makers' intentions. Neoclassical realists believe that while the state does not really know the actual intentions of other states, this does not mean that it automatically treats them as hostile. States can try to determine what these intentions are or even change them with respective ac-

3 'Konstytucja RP', Prezydent.pl: available at https://www.prezydent.pl/prawo/konstytucja-rp/ (27 November 2019). 
tions. David M. Edelstein (2002: 2) maintains that states may choose a strategy of cooperation with another country in order to change its intentions. Therefore, this study will also include intentions as a domestic level variable. From this premise stems the third hypothesis:

Hypothesis 3: Poland chose a strategy of engagement with Russia in the hope of altering its intentions towards Poland.

Another important variable in terms of strategic culture is foreign policy decision-makers' perception of the international balance of power. Although Ripsman et al. did not mention it in their model, other works on neoclassical realism discussed it extensively (Kitchen 2010). Poland just like other non-great powers must consider the international system while executing its foreign policy. And this does not apply solely to Russia. Equally important is the fact that Poland is a member of the European Union (EU) and NATO and that it has close ties to the USA.

Therefore, this research will include in the model of neoclassical realism the attitude of Polish foreign policymakers towards the international power balance. It manifests itself in the perception by foreign policy decision-makers of the threats, their countries perceived power and changes in the international system. Thus, the final hypothesis:

Hypothesis 4: Poland tried to improve relations with Russia due to perceived changes in the international balance of power by Polish decision-makers.

\section{Methodological framework}

This article shall employ the method of systematic process analysis, specified by Peter A. Hall (2006), used to identify which theoretical explanations best explain outcomes and contains four steps. The first is theory formation, where one must identify potential variables and plausible causal relations among them leading to the outcome (Hall 2006: 27), in this case the policy of engagement pursued by Poland towards Russia in 2005-2007. This step has already been performed in the previous section.

Following the logic of systematic process analysis, the next step is to derive "predictions about the patterns that will appear in observations of the world if the theory is valid and if it is false," based on chosen variables (Hall 2006: 27). Hall claims it is best to make several rivalling predictions stemming from different theories, to make the potential inferences more valid. Due to limits of space, this article (which is not by any means exceptional in this regard, [Hall 2006: 29]) shall focus solely on predictions derived from neoclassical realism. However, an element of theoretical rivalry is added by the fact that this article tests 4 hypothesis. 
Hence, if hypothesis 1 holds, it should be visible from the data, that Polish foreign policymakers perceived the possibility of losing their power positions to be high and the only way to secure it was by pursuing a policy of engagement towards Russia, favoured by certain interest groups, capable of removing the decision-makers from power. In the case of hypothesis 2 being true, Polish foreign policy decision-makers should perceive relations with Russia to be an important part of Poland's domestic political struggle and one of the ways to distinguish one's party identity from its rivals was the policy of engagement towards Russia. For hypothesis 3 to be accepted, the data must show that Polish foreign policymakers perceived Russia's intentions and thus its policy towards Poland to be alterable and that this could be achieved with a policy of engagement. Finally, hypothesis 4 foresees that Polish foreign policy decision-makers saw a policy of engagement towards Russia as necessary to improve Poland's position in the European balance of power.

The third step foreseen by systematic process analysis is making observations. It is necessary to analyse processes by which the identified variables operate. As Hall (2006: 26) states: "The point is to see if the multiple actions and statements of the actors at each stage of the causal process are consistent with the image of the world implied by the theory." Thus, following the logic of systematic process analysis and neoclassical realism, in the next parts of this article Poland's relations with Russia in 2005-2007 will be analysed first by reviewing the position of Poland and Russia in the international system of states and subsequently, the domestic level of Polish foreign policymaking towards Russia will be reviewed.

At the last stage of systematic process analysis, the observations must be compared with the theoretical predictions and judgments on the validity of the hypotheses must be made (Hall 2006: 28). This will be done in the penultimate part of the article.

\section{The Systemic Aspect of Polish-Russian Relations in 2005-2007}

This article shall use a classification of states proposed by David R. Mares (1988), presented earlier. In 2005-2007 Poland was part of the European international system which included five major powers: Russia, the United Kingdom, France, Germany and the USA. It is debatable whether the USA and Russia should be differentiated from this group as great powers. Although both countries were each by far stronger militarily than Germany, the UK or France, certain factors mitigated this misbalance. Russia was economically weak, while the relatively small US army in Europe and the sheer geographic distance between America and Europe to a certain extent limited the scope to project its power to the European continent. As Randall L. Schweller (2017: 4) argues, "major powers are great powers of the second rank because they do not possess either a complete portfolio 
of state-of-the-art capabilities or the critical mass (territory and population) or both to qualify as poles." Thus, it is fully justifiable to treat Russia and the USA in Europe as major powers, especially as it was impossible to say that balancing in Europe was focused solely around the USA and Russia in 2005-2007. Moreover, Germany, France and the UK were not only strong economically, but also played a significant role in the EU, which increased these countries' position in the European balance of power vis-à-vis Russia and the USA.

On paper there were two identifiable political blocks in this system. On the one hand there was the EU and NATO with its member states. On the other, Russia with Belarus, its closest ally in Europe. Nevertheless, it cannot be claimed that the system in 2005-2007 was bipolar. First of all, there was no cohesive, co-ordinated policy between Western states and especially its major powers towards Russia. Secondly, the major powers in the system pursued a mix of balancing and bandwagoning strategies towards one another. For instance, the UK was trying to preclude French and German hegemony in the EU, bandwagoned with the USA in the Middle East and confronted Russia on many issues, whereas Germany was co-operating with France and Russia to counterbalance what they perceived as USA unilateralism. Thus, the European international system was multipolar and this created a permissive strategic environment for Poland.

In this constellation Poland was a mid-level power. Such a classification can be justified with the most basic data used by realists to classify states. In terms of population, Poland during 2005-2007 was the $6^{\text {th }}$ largest country in the EU. However, it was weak economically. The size of Poland's GDP ranked only $10^{\text {th }}$ in the EU in 2005, edging up to the $9^{\text {th }}$ position in 2006 and 2007. Per capita, however, Poland's GDP was one of the lowest in the EU. In 2005 it ranked $23^{\text {rd }}$ among the then 25member states, and in 2006 and 2007 Poland was the EU's poorest country in per capita terms. ${ }^{4}$ But most importantly, referring back to Mares's (1988) classification of states, Poland could exert an impact on the European international system only by co-opting other states on its side. The example par excellence was the Orange Revolution in Ukraine in 2004-2005 when Poland, through joining forces with Lithuania, influenced the EU to develop deeper relations with Ukraine and become more engaged in its politics.

From the perspective of Poland's relations with Russia, the most striking is the asymmetry of power in Polish-Russian relations. Moreover, this asymmetry was aggravated by Poland's geographical position. No natural barriers separate it from Russia, as both countries are located on plains. This meant that Russia had a clear offensive advantage against Poland in 2005-2007. To add, at that time NATO was prioritising anti-terrorist and peacekeeping operations beyond NATO's territory rather than collective defence. Poland wished it was otherwise, and for that reason it participated in the Baltic air policing mission in 2006,

4 Author's calculations based on Eurostat. 
supported Estonia during the Bronze Soldier of Tallinn incident and continued its participation in the Iraq and Afghanistan wars to prove Poland's credibility as a NATO ally. $^{5}$

Second, Poland had diametrically different interests from Russia regarding the future orientation of post-Soviet states. In 2003-2005 a series of political changes swept across the post-Soviet space. In Georgia and Ukraine crony, semi-authoritarian Moscow-orientated political regimes were replaced by democratic politicians who mostly favoured Euro-Atlantic integration and a pro-Western foreign policy. Although these developments were positive from Warsaw's point of view, Russia opposed them. This increased tensions between Poland and Russia, as any spontaneous protest movement or crisis situation in the post-Soviet space was treated by both parties as a potentially revolutionary moment pitting the West against Russia.

Third, the period 2005-2007 marks Russia's increased confidence and assertiveness in the international arena, which stemmed from the stabilisation of Russia's internal political model. Vladimir Putin had eliminated all major political opponents and secured loyalty from Russia's richest and most powerful oligarchs. Rising energy prices also helped. ${ }^{6}$ These developments increased Russia's ability to mobilise resources to pursue more expansionist foreign policy aims and its leverage on numerous European countries, including Poland. It is worth noting here that Poland was importing most of its gas and oil from Russia. All these trends meant that Poland faced a clear threat from Russia: at best the two countries' political interests would clash, at worst Russia could present a tangible threat to Poland's political sovereignty and statehood. This means that there was a relatively high degree of systemic clarity for Poland.

Based on this strategic evaluation, one would expect Poland to try and balance Russia's political and military power. In order to do so, as a middle power Poland had to find other allies in this endeavour if it were to exert a meaningful impact on the European international system. But this was not exactly how Poland responded to its strategic environment in 2005-2007.

\section{Poland's Policy towards Russia in 2005-2007}

In late 2005, after PiS had won both parliamentary and presidential elections, it had to devise its own informal formula on foreign policy decision-making. It turned out that the main decision-making centres in both PiS governments were focused around president Lech Kaczyński, his presidential staff and the chiefs of the Polish Ministry of Foreign Affairs (MFA). ${ }^{7}$ In the first government led by

5 Interview Government-MFA expert 1.

6 Interview with MFA employee 4.

7 Interview with Member of Parliament 1; Interview with MFA employee 5. 
Kazimierz Marcinkiewicz, this was Stefan Meller, while in the second, headed by Jarosław Kaczyński - Anna Fotyga and her deputy Paweł Kowal.

From the start, PiS politicians clearly stated their intentions to improve relations with Russia, which were then in a state of crisis due Poland's involvement in Ukraine's Orange revolution, disputes regarding the NordStream pipeline and history (Eberhardt 2006: 115-123). In his New Year's Eve greeting to the Polish nation, president Kaczyński expressed his hopes that the year 2006 would mark a positive breakthrough in Poland's relations with Russia. ${ }^{8} \mathrm{He}$ repeated this later when meeting foreign ambassadors accredited to Poland. ${ }^{9}$ Stefan Meller (2006) emphasised in his exposé that there were no objective conditions and obstacles for Poland and Russia not to pursue neighbourly co-operation based on rationally devised national interests. Crucially, before becoming minister, Meller had been Poland's ambassador to Russia. This was a clear sign of the importance that Warsaw put in its relations with Moscow ${ }^{10}$ (Kowal 2012: 199). One of the minister's first visits was to Moscow, where he met his Russian counterpart Sergei Lavrov and agreed to re-establish the work of the Polish-Russian intergovernmental group on economic co-operation, to reactivate the work of the group on difficult matters, inter-resort consultations and to establish a direct contact between the two ministers of foreign affairs.

Poland persevered further with its policy of engaging Russia. Firstly, the Polish MFA worked out a blueprint for renewing relations with Russia. An amicable ambiance was to be created in Polish-Russian relations through culture. The plan was to follow through with Poland's and Russia's presidents meeting in Kaliningrad Oblast, where they would embark on a ship and travel to Gdansk. The concept was presented to Russia's MFA - which vehemently opposed the project, and to the administration of Russia's president, where the reception was more positive. ${ }^{11}$

Nevertheless, these Polish attempts at engaging Russia did not bring about the desired results. Almost immediately after PiS had taken office, Russia took a number of steps that caused problems for Warsaw. Most importantly, on the $10^{\text {th }}$ of November 2005, during the inaugural speech of Kazimierz Marcinkiewicz as Prime Minister (Cichocki - Świeżak 2008: 67), Russia announced that it had put an embargo on Polish agricultural and meat products. Later in 2006 Russia banned Polish passenger ships from travelling in the Russian part of the Vistula lagoon (Żurawski vel Grajewski 2011: 28) and Moscow continued its NordStream gas pipeline project.

8 'Orędzie noworoczne Prezydenta RP Lecha Kaczyńskiego', Archiwum Lecha Kaczyńskiego (31 December 2005): available at https://www.prezydent.pl/archiwum-lecha-kaczynskiego/ (20 June 2019).

9 'Noworoczne spotkanie Prezydenta RP z Korpusem Dyplomatycznym', Archiwum Lecha Kaczyńskiego (10 January 2006): available at https://www.prezydent.pl/archiwum-lecha-kaczynskiego/(20 June 2019).

10 Interview with MFA employee 5.

11 Interview with MFA employee 1. 
The Polish side considered these Russian actions as a test of Western support that Poland would be able to garner in its dispute with Russia as well as of Poland's capabilities in forming the EU's policy towards Russia. ${ }^{12}$ Moreover, these measures were also designed to discredit the EU's enlargement policy in the eyes of the main Western capitals. ${ }^{13}$ This was important given that Poland was still a newcomer in the EU and Ukraine's potential membership of the EU had only recently emerged as a possibility. This interpretation seemed to be confirmed by the fact that Russia took disproportionate measures in response to irregularities found in Polish meat and agricultural products. ${ }^{14}$

Numerous attempts were made by Polish diplomats and politicians to solve this issue with Russia on a bilateral basis. ${ }^{15}$ At the same time Poland was lobbying other EU member states for support in its trade dispute with Russia, since the EU had a vantage point in negotiating trade relations with third parties.

Nevertheless, a new attempt at engaging Russia soon emerged. Polish diplomats invited to Poland Sergey Yastrzhembsky, then Russia's president's influential advisor of Polish origin. He visited Warsaw in February 2006 and delivered a letter from Putin to Lech Kaczyński, in which the Russian president expressed his wishes to normalise relations with Poland. The Polish side once again presented the concept of revitalising Polish-Russian relations through culture. ${ }^{16}$ Yastrzhembsky then met with Meller to discuss the potential meeting of the countries' presidents. Yastrzhembsky was also received by Poland's prime minister and a government think-tank, the Polish Institute of International Affairs. ${ }^{17}$

Poland further tried to engage Russia. To that end, the Polish authorities tried to organise a meeting between the two presidents. Russia refused to succumb to Lech Kaczyński's request that the Russian president should first visit Poland rather than vice versa. ${ }^{18}$ The Head of the Chancellery of the President of Poland, Aleksander Szczygło, suggested that presidents of Poland and Russia should meet in 2006 on neutral ground. ${ }^{19}$ Later Andrzej Krawczyk, undersecretary of state at the Chancellery of the President of Poland, repeated that Vladimir Putin had an invitation to visit Poland and that works on the details of the meeting between presidents would continue. ${ }^{20} \mathrm{He}$ accepted that the sidelines

\footnotetext{
12 Interview with MFA employee 4.

13 Interview with MFA employee 5.

14 Interview with MFA employee 5.

15 Interview with Member of Parliament 1.

16 Interview with MFA employee 1.

17 Interview with MFA employee 1.

18 Interview with MFA employee 1; Interview with MFA employee 2.

19 'Potrzeba dużej rozwagi i spokoju', Archiwum Lecha Kaczyńskiego (7 August 2006): available at https:// www.prezydent.pl/archiwum-lecha-kaczynskiego/ (20 June 2019).

20 'Prezydent Putin ma otwarte zaproszenie do Polski', Archiwum Lecha Kaczyńskiego (8 August 2006): available at https://www.prezydent.pl/archiwum-lecha-kaczynskiego/ (20 June 2019).
} 
of the EU-Russia summit scheduled in Finland in late 2006 could be one of the venues for the presidents to meet. ${ }^{21}$ Other places under consideration were the Vistula lagoon or Belarus (Eberhardt 2007: 134-135).

Poland continued its attempts at engaging Russia in other spheres as well. In June 2006 the chief of Poland's National Security Bureau Władysław Stasiak visited Moscow, where he met Igor Ivanov, the head of Russia's Security Council. Both parties discussed regional as well as international matters of security and the planned US anti-missile shield installations in Poland. ${ }^{22}$ In addition, Paweł Kowal was frequently visiting Moscow to discuss and resolve bilateral issues in Polish-Russian relations..$^{23}$ Later, in September 2006 joint Polish-Russian-Danish-Swedish naval exercises took place in the Baltic Sea to improve co-operation in countering trafficking of materials for the production of weapons of mass destruction. ${ }^{24}$ To add, science and culture remained two important fields where Poland and Russia worked closely with each other. ${ }^{25}$ Moreover, contacts and dialogue had been established between the Catholic Church in Poland and the Russian Orthodox Church. ${ }^{26}$

On the $5^{\text {th }}$ of October 2006 the Russian Foreign Minister Sergey Lavrov visited Warsaw, where he met with Lech and Jarosław Kaczyński and Anna Fotyga. With the Polish president, he discussed the implications of NordStream pipeline. Both parties agreed to resolve the issue of the trade embargo as quickly as possible and to organize a meeting between Putin and Kaczyński the following year. In addition, they discussed the issue of the US anti-missile shield in Poland and possible co-operation with Russia within the EU and NATO. Both sides expressed their wishes to improve relations through political dialogue, cultural initiatives and economic co-operation.

During the same visit, Sergey Lavrov met Anna Fotyga and discussed problematic issues in the bilateral relations. They also agreed to organise an economic presentation in Poland of Kaliningrad Oblast and a festival of Russian culture and science in Poland. In addition, it was decided to revive the activity of the Polish-Russian group on difficult matters and schedule a plan of consultations between the two countries' MFAs. Both sides also discussed a number of international issues, including EU-Russia relations and the upcoming negotiations on the new EU-Russia partnership treaty, Iran's nuclear program,

21 'Prezydent jest aktywny', Archiwum Lecha Kaczyńskiego (9 August 2006): availabe at https://www. prezydent.pl/archiwum-lecha-kaczynskiego/ (20 June 2019).

22 'Szef BBN na rozmowach w Moskwie', Biuro Bezpieczeństwa Narodowego: available at https://www. bbn.gov.pl/pl/wydarzenia/967,dok.html (20 June 2019).

23 Interview with Member of Parliament 1.

24 'Amber Sunrise 2006', Proliferation Security Initiative: available at https://psi.msz.gov.pl/pl/cwiczenia/ amber_sunrise_2006/(20 June 2019).

25 Interview with MFA employee 3.

26 Interview with Member of Parliament 1. 
the situation in Lebanon, Iraq, Afghanistan and the frozen conflicts in the post-Soviet region. The two ministers noted huge similarities in Poland's and Russia's positions on these issues. ${ }^{27}$

Although there were no signs of a Putin-Kaczyński meeting in sight, the two had an opportunity to meet each other in the EU-Russia summit in Finland in late October 2006. During an informal meeting between all EU leaders and Vladimir Putin, Lech Kaczyński stressed the situation in Georgia, ${ }^{28}$ raised the issue of the murder of Anna Politkovskaya, ${ }^{29}$ and argued that Russia should accept the EU energy charter and that EU solidarity in energy should be strengthened. ${ }^{30}$

At the end of November 2006, Russia made a public move in response to Poland's policy of balancing and engagement towards it. President Putin wrote an article for the Polish newspaper Dziennik, in which he argued, that Russia belonged to the European family and warned against the rhetoric implying that Europe was too dependent on Russia. According to Putin, this was unfounded and only served to raise new divisions in Europe. ${ }^{31}$ One interpretation of the Russian president's move is that it was a reaction to the spreading rumours that Poland might veto the European Commission's mandate to negotiate a new EU-Russia partnership treaty.

Despite Polish efforts to engage Russia, there was no progress made on Russia lifting its trade embargo and neither did Poland find sufficient support from other EU members nor the European Commission in resolving this issue. As a result, in November 2006 Poland decided to veto the European Commission's mandate to negotiate a new Partnership and Co-operation Agreement between the EU and Russia in order to make the European Commission get more involved in Poland's trade dispute with Russia. ${ }^{32}$ President's spokesperson Maciej Łopiński confirmed that Poland would withdraw its veto once Russia lifted its trade embargo. ${ }^{33}$

27 'Komunikat dot. wizyty w Polsce Ministra Spraw Zagranicznych Federacji Rosyjskiej Pana Siergieja Ławrowa', Archiwum Ministerstwa Spraw Zagranicznych (6 October 2006): available at https://www. msz.gov.pl/pl/aktualnosci/archiwum/ (20 June 2019).

28 'Drugi dzień wizyty w Finlandii', Archiwum Lecha Kaczyńskiego (20 October 2006): available at https:// www.prezydent.pl/archiwum-lecha-kaczynskiego/ (20 June 2019).

29 'Maciej Łopiński w Trójce, 24 października 2006 r.', Archiwum Lecha Kaczyńskiego (24 October 2006): available at https://www.prezydent.pl/archiwum-lecha-kaczynskiego/ (20 June 2019).

30 '10 minut z Putinem to nie to, o co nam chodzi', Archiwum Lecha Kaczyńskiego (19 October 2006): available at https://www.prezydent.pl/archiwum-lecha-kaczynskiego/ (20 June 2019).

31 'Według Putina Rosja należy do Europy', WP wiadomości (22 November 2006): available at https:// wiadomosci.wp.pl/wedlug-putina-rosja-nalezy-do-europy-6036190391280769a (20 June 2019).

32 'UE musi zacząć dostrzegać i akceptować nasze interesy', Archiwum Lecha Kaczyńskiego (25 November 2006): available at https://www.prezydent.pl/archiwum-lecha-kaczynskiego/ (20 June 2019).

33 'Maciej Łopiński w Sygnałach Dnia, 30 listopada 2006 r.', Archiwum Lecha Kaczyńskiego (30 November 2006): available at https://www.prezydent.pl/archiwum-lecha-kaczynskiego/ (20 June 2019). 
Apart from the veto, Poland's actions in balancing Russia were noticeable in other areas, especially in energy. In December 2006 Poland finalised its investment in Lithuania, where PKN Orlen bought the Mažeikiai oil refinery from JUKOS. One of the main reasons for this purchase was that Poland intended to prevent Russia from gaining dominance in the regional petrol markets. ${ }^{34}$ In May 2007 Poland organised a summit in Krakow together with Lithuania, South Caucasus and the Central Asian states dedicated to diversification of energy supplies to Central and Eastern Europe. ${ }^{35}$ This liaising was continued in October 2007 in Vilnius. ${ }^{36}$ The outcome of the summit was a memorandum to build the Odessa-Gdansk oil pipeline. ${ }^{37}$ In June 2007 Lech Kaczyński participated in the $\mathrm{GUAM}^{38}$ summit, where he gave public support for energy co-operation with GUAM countries and for its Euro-Atlantic aspirations. ${ }^{39}$ Poland was also simultaneously pushing for a common EU stance on energy.

Although, following the veto the Polish rhetoric towards Russia became harsher, attempts at engaging Russia were not abandoned. In December 2006 the Weimar Triangle meeting took place. Germany, France and Poland jointly declared that they recognized Russia as a strategic partner and would continue to support the development of co-operation with Russia on equal basis in relation to common interests, especially in trade and energy. ${ }^{40}$ At the beginning of 2007, Krawczyk announced that Poland wanted to improve relations with Russia and that would be one of the main priorities in the following year. ${ }^{41}$ Lech Kaczyński himself often repeated that there was a possibility of reaching a compromise on Poland's veto regarding the EU-Russia treaty. ${ }^{42}$ In her exposé Anna Fotyga (2007) affirmed that Poland was interested in developing co-operation and dialogue with Russia in the fields of history, culture, economy and in strengthening ties between Russian and Polish local municipalities.

34 Interview President's chancellery's employee 1.

35 'Minister Łopiński w Sygnałach Dnia 11 Maja 2007 r.', Archiwum Lecha Kaczyńskiego (11 May 2006): available at https://www.prezydent.pl/archiwum-lecha-kaczynskiego/ (20 June 2019).

36 'Wizyta Prezydenta RP w Wilnie', Archiwum Lecha Kaczyńskiego (10 October 2007): available at https:// www.prezydent.pl/archiwum-lecha-kaczynskiego/ (20 June 2019).

37 'Studio Wschód, TVP3, 10 października 2007 r.', Archiwum Lecha Kaczyńskiego (10 October 2007): available at https://www.prezydent.pl/archiwum-lecha-kaczynskiego/ (20 June 2019).

38 A regional grouping made of Georgia, Ukraine, Azerbaijan and Moldova.

39 'Prezydent RP gościem specjalnym szczytu GUAM w Baku’, Archiwum Lecha Kaczyńskiego (19 June 2007): available at https://www.prezydent.pl/archiwum-lecha-kaczynskiego/ (20 June 2019).

40 'Budowa Europy pozostaje projektem dla przyszłych pokoleń', Archiwum Lecha Kaczyńskiego (5 December 2006): available at https://www.prezydent.pl/archiwum-lecha-kaczynskiego/ (20 June 2019).

41 'Tok FM, 16 stycznia 2007 r.', Archiwum Lecha Kaczyńskiego (16 January 2007): available at https://www. prezydent.pl/archiwum-lecha-kaczynskiego/ (20 June 2019).

42 'Udział prezydenta RP w posiedzeniu Rady Europejskiej', Archiwum Lecha Kaczyńskiego (15 December 2006): available at https://www.prezydent.pl/archiwum-lecha-kaczynskiego/ (20 June 2019). 
Despite the embargo, Poland's president searched for other ways to establish contacts with Russia. One possibility was increasing regional co-operation between Poland and Kaliningrad Oblast. ${ }^{43}$ Another example took place in May 2007. The first ladies of Poland and Russia, Maria Kaczyńska and Lyudmila Putina, met in Saint Petersburg to open the Polish House. ${ }^{44}$ On the sidelines of this event the first ladies together with their countries' diplomats discussed the potential normalisation of Polish-Russian relations ${ }^{45}$ (Kowal 2012: 200). In fact, some claim that both countries at that point were close to reaching an agreement to normalise relations. In the Russian MFA, Poland's behaviour was seen as irrational, but causing too much trouble for Russia, thus a necessity to come to terms with Poland was growing. ${ }^{46}$ But once it became clear, during the summer of 2007, that Poland was heading to pre-term parliamentary elections, Russia gave up these thoughts.

However, even during the electoral campaign Poland consequentially continued its policy of engagement towards Russia. In September 2007 Lech Kaczyński visited Smolensk, where he participated in commemorations of the Katyn massacre. ${ }^{47}$ During the ceremony Lech Kaczyński argued that Poland acknowledged Russia's important role in Europe and globally, and that it wanted to have good relations with Russia, but they should be based on truth. ${ }^{48}$

Let us not forget that Poland still managed to achieve its goal, for the sake of which the decision to veto the start of negotiations of a new EU-Russia treaty had been made. In May 2007, during the EU-Russia summit in Samara, German Chancellor Angela Merkel, who also happened to hold the EU presidency at that time, stated that Poland's trade dispute with Russia was an EU level matter.

Judging by Polish diplomats' and politicians' rhetoric, the issue of the USA building part of its anti-missile defence shield on Poland's territory seemed to be a problem in Polish-US and US-Russian, but not Polish-Russian relations. For instance, Andrzej Krawczyk dismissed Russia's opposition to stationing the missile defence shield in Poland as institutional noise and claimed that it had nothing to do with Polish-Russian relations. ${ }^{49}$ Having met with George W. Bush in July 2007 Lech Kaczyński stated that the anti-missile shield was of defensive

43 'PAP, 2 stycznia 2007 r.', Archiwum Lecha Kaczyńskiego (2 January 2007): available at https://www. prezydent.pl/archiwum-lecha-kaczynskiego/ (20 June 2019).

44 'Wizyta Pani Prezydentowej w Sankt Petersburgu', Archiwum Lecha Kaczyńskiego (13 May 2007): available at https://www.prezydent.pl/archiwum-lecha-kaczynskiego/ (20 June 2019).

45 Interview with Member of Parliament 1.

46 Interview with MFA employee 2.

47 'Wizyta Pani Marii Kaczyńskiej w Katyniu', Archiwum Lecha Kaczyńskiego (17 September 2007): available at https://www.prezydent.pl/archiwum-lecha-kaczynskiego/ (20 June 2019).

48 'Uroczystości w Katyniu', Archiwum Lecha Kaczyńskiego (17 September 2007): available at https://www. prezydent.pl/archiwum-lecha-kaczynskiego/ (20 June 2019).

49 'Magazyn TVN24, 11 października 2006 r.', Archiwum Lecha Kaczyńskiego (11 October 2006): available at https://www.prezydent.pl/archiwum-lecha-kaczynskiego/ (20 June 2019). 
nature, directed to protect Poland against rogue, unpredictable regimes, suggesting, that Russia did not belong to such a category of states. ${ }^{50}$ Still, other sources $^{51}$ (Sikorski 2018: 137-146) show that Poland's negotiations with the USA on the anti-missile shield were part of a policy to balance Russia, since Warsaw was trying to persuade Washington to increase US security guarantees for Poland from a potential Russian attack in exchange for the permission to station the anti-missile defence shield.

On the $21^{\text {st }}$ of October 2007, the pre-term parliamentary elections in Poland were overwhelmingly won by the Civic Platform party (Polish: Platforma Obywatelska, PO) which formed a new coalition government with the Polish People's Party (Polish: Polskie Stronnictwo Ludowe, PSL). This marked the end of PiS's control of Poland's foreign policy. Although Lech Kaczyński remained president, he was essentially excluded from foreign policy decision-making by the PO government.

\section{The Drivers behind Poland's Attempts to engage Russia}

As shown above, Poland pursed a mixed strategy of balancing and engagement towards Russia in 2005-2007, while PiS was in power. Whereas the reasons for Poland's balancing are obvious given the power asymmetry and different interests between Poland and Russia, the question arises why Poland was at same time pursuing engagement towards Russia.

\section{Hypothesis 1}

Although during 2005-2007 PiS was in a coalition with Self Defence (Polish: Samoobrona) and the League of Polish Families (Polish: Liga Polskich rodzin) parties, which did not hide their pro-Moscow foreign policy views, and in the case of the latter there were even suspicions of ties to Russian business and intelligence services, ${ }^{52}$ it had no effect on Poland's policy towards Russia. The parties' portfolios in the government were not related to foreign policy and the Polish parliament in 2005-2007 had little influence on Poland's policy towards Russia.

Russia did indeed try to influence Polish politics through Samoobrona and Liga Polskich Rodzin. For instance, two honoris causa doctoral titles for Samoobrona's leader Andrzej Lepper were awarded in Moscow, along with invitations to visit Russia for Samoobrona activists and support for common projects. There were also attempts to gratify nationalists linked to Liga Polskich Rodzin..$^{53}$ But

\footnotetext{
50 'Prezydent RP w Stanach Zjednoczonych', Archiwum Lecha Kaczyńskiego (16 July 2007): available at https://www.prezydent.pl/archiwum-lecha-kaczynskiego/ (20 June 2019).

51 Interview Government-MFA expert 1.

52 Interview with Member of Parliament 2.

53 Interview with MFA employee 3.
} 
Russia's actions brought no results, as PiS coalition partners were completely isolated from foreign policy decision-making.

Moreover, Polish business was also marginalised from it ${ }^{54}$ and neither did public opinion or media outlets had an effect on Poland's decisions. Rather, decision-making was concentrated around the President and the MFA chiefs, who viewed Poland's foreign policy and its relations with Russian in the same manner and made their decisions independently, without any external interference or pressure. Thus, there was no evidence found that any interest group affected Poland's policy towards Russia in 2005-2007.

\section{Hypothesis 2}

There were no internal political motivations guiding Poland's policy towards Russia in 2005-2007. All of the main foreign policy decision-making posts belonged to one political group - PiS, so it had full control of all available resources to be mobilised for foreign policy execution and did not need to compete in that with any political group. Furthermore, the opposition, especially PO, fully supported Poland's actions towards Russia, including the decision to veto the European Commission's mandate to negotiate an EU-Russia partnership deal.

Although the then oppositional PSL which had a strong electoral base among Poland's farmers was pressuring the Polish government to renew trade with Russia, as Poland's agriculture suffered losses due to Russia's embargo, PiS politicians treated such discourse as an attempt by PSL to appeal to its electoral base, which would not affect PiS's rankings in opinion polls. Thus, Poland's policy towards Russia in 2005-2007 was not part of the internal political debate and therefore it did not produce any incentives, which could potentially pressure foreign policy decision-makers to pursue engagement towards Russia.

\section{Hypothesis 3}

There is strong evidence to suggest that Poland aimed to change Russia's intentions towards it. Poland's policy's aim was not only to change Russia's perception of Poland as a country inherently unfriendly towards Russia, but also to make sure that Russia did not pursue its sphere of influence policy. ${ }^{55}$ Bilateral meetings with Russian politicians and diplomats, and the cultural, regional and economic co-operation were intended to demonstrate that Poland had no malign intentions towards Russia, which henceforth should have fastened the process of Russia coming to terms with Poland's sovereignty.

For instance, at the end of September 2007, president Lech Kaczyński visited the USA, where in a lecture on Polish foreign policy he stated that the sole

54 Interview with Member of Parliament 2.

55 Interview with MFA employee 1. 
problem in Polish-Russian relations was Russia's inclination to treat Poland as part of its own sphere of influence. Russia's use of energy for political reasons or historical disagreements were also mentioned, but they were not as important as the former. Otherwise, according to Kaczyński, Poland did not see in Russia any military or political threat and it was ready to pursue normal relations based on partnership..$^{56}$ Elsewhere, he noted that the unwillingness of the governing circles in Russia to accept that Poland was a sovereign country, and a member of both the EU and NATO, and with its own interests was the main obstacle in organising meeting between Poland's and Russia's presidents. ${ }^{57}$

What is not so evident from first glance is that Poland's political leaders from 2004 onwards had perceived that Poland's power had increased along with its capability to change its relations with Russia. According to this thinking, NATO had provided Poland security, which had significantly diminished Russia's military threat, whereas EU membership had provided Poland with new instruments to form its policy towards Russia. ${ }^{58}$ This line of thought was confirmed in Poland's 2007 National Security Strategy, which stated that Poland did not foresee any large scale conflicts, only lower-intensity regional clashes in which Poland would not be involved. ${ }^{59}$

For example, in May 2007 Lech Kaczyński announced that the EU might block Russia's access to WTO unless it lifted its embargo. He also repeated that Poland was not interested in confrontation with Moscow and that it wanted sincere co-operation with Russia, not one which implied Russian dominance in Central Eastern Europe. ${ }^{60}$

In numerous interviews, Lech Kaczyński appeared to genuinely believe that it was possible to persuade Russia to refrain from seeking influence in Central Eastern Europe ${ }^{61}$ Kaczyński expressed similar views when commenting the US anti-missile shield in Poland after meeting G. W. Bush in June 2007: he argued that Russia had to understand that the world had moved on, especially in Central Eastern Europe. ${ }^{62}$ In similar mode Anna Fotyga (2007) expressed her exposé Poland's desire to start negotiating a new EU-Russia treaty, and

56 'Lech Kaczyński w Chicago', Archiwum Lecha Kaczyńskiego (25 September 2007): available at https:// www.prezydent.pl/archiwum-lecha-kaczynskiego/ (20 June 2019).

57 'Rozsądek i pamiętanie o przeszłość', Archiwum Lecha Kaczyńskiego (22 August 2006): available at https://www.prezydent.pl/archiwum-lecha-kaczynskiego/ (20 June 2019).

58 Interview with MFA employee 4.

59 'Strategia Bezpieczeństwa Narodowego RP 2007', Biuro Bezpieczeństwa Narodowego: available at https:// www.bbn.gov.pl/pl/wydarzenia/1142,Strategia-Bezpieczenstwa-Narodowego-RP.html (20 June 2019).

60 'L. Kaczyński: UE może zablokować wejście Rosji do WTO', Wprost (27 May 2007): available at https:// www.wprost.pl/swiat/107224/komandosi-opuszczaja-kijow.html (20 June 2019).

61 Interview with MFA employee 1; Interview with Member of Parliament 1.

62 'Prezydent RP spotkat się z prezydentem Stanów Zjednoczonych', Archiwum Lecha Kaczyńskiego (8 June 2007): available at https://www.prezydent.pl/archiwum-lecha-kaczynskiego/ (20 June 2019). 
confirmed the necessity of such a treaty, on condition that Russia began to treat all EU member states equally.

This stance was strengthened by the perception on part of the PiS leadership of Russia that they had developed in the 1980s while participating in the Solidarity movement. For them Russia had the potential to overcome its imperial past and become a humanist force in international politics, becoming an advocate of moral politics instead of power politics. ${ }^{63}$ Such hopes were harboured towards Russia's intelligentsia and political and cultural dissidents. For instance, during the ceremony of awarding the Jerzy Giedroyc prize, Lech Kaczyński remarked that the situation inside Russia was disturbing and had a great effect on the decisions made in Poland and in Europe generally. He also noted that the intelligentsia did not have any influence on Russia's politics and expressed his hopes that that would change in the future, ${ }^{64}$ implying that such a development would democratise Russia and its foreign policy.

\section{Hypothesis 4}

There is a substantial amount of evidence that by engaging Russia, Poland tried to improve its standing in the EU, NATO and among the major Western countries. One of Poland's main foreign policy goals was to support the sovereignty of countries located between Poland and Russia - Belarus and Ukraine - in this way hoping to diminish Russia's influence in the region and hence increase Poland's own security. Therefore, Poland actively supported the Euro-Atlantic integration of Ukraine, but also Georgia, Moldova, and potentially Belarus, Armenia, and Azerbaijan, and the idea of the EU and NATO eastward enlargement. In order to achieve this goal, Poland endeavoured to garner support from the main Western powers.

However, the majority of Polish foreign policy decision-makers feared that Poland had a reputation in most Western countries of an irresponsible country, whose foreign policy, including active support for NATO and EU expansion, was guided purely by irrational 'Russophobia.' Such accusations were constantly made by France and Germany. ${ }^{65}$ Hence, attempts at engaging Russia were meant to show the Western countries that Poland had no malign intentions towards Russia and that it was a responsible member of the EU and NATO, which always took into consideration these organisations' common interests and was not aiming to disrupt the EU-Russian and NATO-Russian relations for the sake of Polish particularistic interests. It was expected that Poland's engagement with Russia would eventually convince other EU and NATO members, especially

\footnotetext{
63 Interview with MFA employee 1; Interview with Member of Parliament 1.

64 'Chcielibyśmy normalnego ułożenia stosunków z Rosją', Archiwum Lecha Kaczyńskiego (9 November 2006): available at https://www.prezydent.pl/archiwum-lecha-kaczynskiego/ (20 June 2019).

65 Interview with MFA employee 1.
} 
those in Western Europe, that Poland's propositions regarding Russia and the EU's and NATO's eastern neighbours were motivated by seeking a common good for the sake of all countries and not by Poland's anti-Russian views.

Hence, Poland's engagement policy towards Russia was not only directed towards Moscow, but towards Western capitals as well. Poland thought that good relations with Russia and the reputation of an expert on Russia would help the country to increase its standing in the EU generally. ${ }^{66}$ An example of this approach is Lech Kaczyński's speech to the foreign diplomats accredited in Poland, in the beginning of 2006:

I would like to express hope that the year 2006 will be the year in which we are able to improve considerably these relations [with Russia], though I understand that this is a specific process. I would like to say to representatives of all countries accredited in Poland that there are no obstacles on our side. There are no obstacles, because there is no Russofobia, of which we are often being accused. There is no such stance, there is only our will to co-operate on principles of partnership. ${ }^{67}$

In another case, Anna Fotyga visited Moscow, where she participated in a conference dedicated to co-operation in fighting drug trafficking. This issue and the event itself were only of secondary importance for Poland. As a matter of fact, Fotyga's attendance was a deliberate display of Poland's goodwill towards Russia, ${ }^{68}$ as Lech Kaczyński pointed out later, commenting that the West had to understand that it took two sides to co-operate. ${ }^{69}$

Furthermore, during the already-mentioned Jerzy Giedroyc award ceremony in 2006, he openly stated that Poland wanted and needed to normalise its relations with Russia, since this would ease Poland's policy towards its Western, Southern and Eastern neighbours. ${ }^{70}$ Later, at the New Year annual meeting with the diplomatic corps in 2007, Lech Kaczyński stated that Poland wanted to have good relations with Russia, and that it wanted to contribute to the maintaining of friendly and positive relationships between the EU and Russia. ${ }^{71}$

Another instance showing that Poland's engagement policy towards Russia was motivated by the country's desire to make an impression on Western countries was Lech Kaczyński's speech at the $61^{\text {st }}$ General debate at the UN general session in September 2006. There, he again declared Poland's wish to have good relations with Russia. But most importantly he brought up the is-

\section{Interview with MFA employee 3.}

67 'Noworoczne spotkanie Prezydenta RP z Korpusem Dyplomatycznym', 2006.

68 Interview with MFA employee 5.

69 'Nowy prezez NBP ma dbać o wzrost gospodarki', Archiwum Lecha Kaczyńskiego (29 June 2006): available at https://www.prezydent.pl/archiwum-lecha-kaczynskiego/ (20 June 2019).

70 'Chcielibyśmy normalnego ułożenia stosunków z Rosją'.

71 'Noworoczne spotkanie z Korpusem Dyplomatycznym', Archiwum Lecha Kaczyńskiego (16 January 2007): available at https://www.prezydent.pl/archiwum-lecha-kaczynskiego/ (20 June 2019). 
sue of Polish-Russian relations in the context of Polish-German relations and reconciliation, which followed the German-French reconciliation's example. ${ }^{72}$ This was a suggestion that Poland and Russia could undergo a similar path of reconciliation as France and Germany or Poland and Germany.

This line of thought, aiming to show that Poland wanted to have good relations with Russia for the benefit of all Europe, was repeated numerous times by Lech Kaczyński's associates. Andrzej Krawczyk argued that there were few countries in Europe that had as many ties with Russia as Poland did, and that it was wrong to claim that Poland was anti-Russian. ${ }^{73}$ He went as far as to say that Poland was Russia's main transit channel to Europe. ${ }^{74}$ In a follow-up press conference after meeting Yastrzhembsky, Meller stated that not only Poland, but also Russia and Europe needed good Polish-Russian relations. ${ }^{75}$

\section{Conclusion}

This article has shown that Poland in 2005-2007, during PiS term in power, pursued a foreign policy towards Russia based on a mix of engagement and balancing. Whereas balancing stemmed from the power asymmetry and diverging strategic interests between the two countries, Poland engaged Russia for two reasons. First, PiS politicians tried to change Russia's intentions towards Poland and sincerely believed that was possible. Second, and most importantly, such engagement was meant to show Western countries, especially those that played the main role in the EU and NATO, that Poland was not a 'Russophobic' country, which tried to entangle the EU and NATO into its drive against Russian imperialism. Poland hoped that it would convince its Western partners that Warsaw's policy propositions, especially support for eastward EU and NATO enlargement, were to increase regional stability and bring benefits for both the West and Russia.

Such findings are entirely commensurate with Poland's status as a middle power in the European international system. One of Poland's main foreign policy's goals was to change the European international system by bringing its Eastern neighbours - especially Ukraine, Moldova and Georgia - as close to Euro-Atlantic institutions as possible so as to push Russia's influence away from

72 'Reformy muszą być skierowane na człowieka', Archiwum Lecha Kaczyńskiego (19 September 2006): available at https://www.prezydent.pl/archiwum-lecha-kaczynskiego/ (20 June 2019).

73 'Zasada równego partnerstwa', Archiwum Lecha Kaczyńskiego (12 September 2006): available at https:// www.prezydent.pl/archiwum-lecha-kaczynskiego/ (20 June 2019).

74 'Sygnały dnia PR 1, 6 października 2006 r.', Archiwum Lecha Kaczyńskiego (6 October 2006): available at https://www.prezydent.pl/archiwum-lecha-kaczynskiego/ (20 June 2019).

75 'Spotkanie Ministra Stefana Mellera z przebywającym z wizytą w Warszawie doradcą prezydenta Federacji Rosyjskiej Panem Siergiejem Jastrzembskim', Archiwum Ministerstwa Spraw Zagranicznych (21 February 2006): available at https://www.msz.gov.pl/pl/aktualnosci/archiwum/ (20 June 2019). 
Poland. In order to do so, Poland needed support from its Western and regional allies, since it did not have enough power to achieve this goal on its own.

Finally, some notes should be made from a theoretical point of view. In relation to the article's theoretical framework, it has been shown that the main variables that caused Poland's engagement policy derived from strategic culture, whereas domestic institutions and state-society relations had no effect.

Secondly, most of the academic literature treats engagement as a separate policy aimed to change the threatening behaviour of another state (Resnick 2001; Cha 2002: 44; Schweller 1998: 74; Edelstein 2002: 5). This article has demonstrated, however, that the engagement policy that Poland pursued towards Russia in 2005-2007 was essentially designed to strengthen its long-term policy aim of balancing Russia by attracting support from Western countries. Thus, it is possible to argue that alongside the traditionally perceived engagement, there exists pragmatic - or 'instrumental' - form of engagement that can be undertaken by small or middle powers in order to improve one's standing among allies rather than to improve relations with the engaged state. Theses findings nuance in some way the opinion widespread in the public sphere and academic literature that during 2005-2007 Poland pursued a purely anti-Russian policy. It cannot be said, that PiS leadership followed blindly their "anti-Russian" views and tried to confront Russia on every occasion. Rather, they analysed the European balance of power, sensed Poland's limitations and tried to adapt Poland's foreign policy with the main trends in EU-Russia relations.

Most importantly, this article has shown that neoclassical realism may be a useful way to solve the problems of the systemic approach to identifying middle powers, which finds it difficult to predict middle powers' behaviour. By employing neoclassical realism in future research and studying middle powers' foreign policy decision-makers more thoroughly it may be possible to devise at least some conditional predictions on middle powers' foreign policy behaviour.

Acknowledgments: The author would like to thank Tomas Janeliūnas, Marek Czajkowski, Rosita Garškaite and anonymous reviewers for their comments in preparing this article.

\section{References}

Acharya, Amitav (1999): Containment, Engagement or Counter-Dominance? Malaysia's response to the rise of China, in Johnston, Alastair I. - Ross, Robert S., ed., Engaging China: The Management of an Emerging Power. 132-154, Routledge, New York.

Antonovič, Marijuš (2018): Studies in Poland's Foreign Policy: the case of Poland-Russia Relations. Warsaw East European Review 8: 123-133.

Barkin, Jack S. (2003): Realist Constructivism. International Studies Review 5(3): 325-342. 
Bleich, Erik - Pekkanen, Robert (2013): How to Report Interview Data, in Mosley, Layna, ed., Interview Research in Political Science. 84-105, Cornell University Press, Ithaca \& London.

Carr, Andrew (2014): Is Australia a middle power? A systemic impact approach. Australian Journal of International Affairs 68(1): 70-84.

Cha, Victor D. (2002): Hawk Engagement and Preventive Defense on the Korean Peninsula. International Security 27(1): 40-78.

Cichocki, Bartosz - Świeżak, Pawet (2008): Co Polska może na Wschodzie? Raport. Bezpieczeństwo Narodowe 7-8: 65-82.

Cimek, Gracjan - Franz, Maciej - Szydywar-Grabowska, Karolina (2012): Wspótczesne Stosunki Polsko-Rosyjskie. Wybrane Problemy, Wydawnictwo Adam Marszatek, Toruń.

Eberhardt, Adam (2006): Stosunki Polski z Rosją, in Kuźniar, Roman, ed., Rocznik Polskiej Polityki Zagranicznej 2006. 115-123, Polski Instytut Spraw Międzynarodowych, Warsaw.

Eberhardt, Adam (2007): Stosunki Polski z Rosją, in Kuźniar, Roman, ed., Rocznik Polskiej Polityki Zagranicznej 2007. 133-145, Polski Instytut Spraw Międzynarodowych, Warsaw.

Edelstein, David M. (2002): Managing uncertainty: Beliefs about intentions and the rise of great powers. Security Studies 12(1): 1-40.

Fotyga, Anna (2007): 'Informacja Minister Spraw Zagranicznych Anny Fotygi na temat polityki zagranicznej RP w 2007 roku.' 11 May: available at: https://www.msz.gov.pl/pl/p/msz_pl/polityka_zagraniczna/priorytety_polityki_zagr_2017_2021/expose2/expose_2007/(20 June 2019).

Gorska, Joanna A. (2010): Dealing with a Juggernaut: Analyzing Poland's Policy towards Russia, 1989-2009, Lexington Books, Plymouth. concept

Jordaan, Eduard (2017): The emerging middle power: Time to say goodbye? South African Journal of International Affairs 24(3): 395-412.

Kaarbo, Juliet (2015): A Foreign Policy Analysis Perspective on the Domestic Politics Turn in IR Theory. International Studies Review 17: 189-216.

Kaczmarski, Marcin - Konończuk, Wojciech (2009): Rosyjski dylemat w polityce zagranicznej Polski po 1999 roku, in Gil, Andrzej - Kapuśniak, Tomasz, eds., Polityka wschodnia Polski: Uwarunkowania, Koncepcje, Realizacja. 203-218, Instytut Europy Środkowo-Wschodniej, Lublin-Warszawa.

Kitchen, Nicholas (2010): Systemic pressures and domestic ideas: a neoclassical realist model of grand strategy formation. Review of International Studies 36(1): 117-143.

Kowal, Paweł (2012): Między Majdanem a Smoleńskiem. Rozmawiają Piotr Legutko, Dobrosław Rodziewicz, Wydawnictwo Literackie, Kraków.

Kuźniar, Roman (2012): Polityka zagraniczna III Rzeczypospolitej, Wydawnictwo Naukowe SCHOLAR, Warsaw.

Lakomy, Miron (2011): Główne problemy w stosunkach polsko-rosyjskich na początku XXI wieku, in Stolarczyk, Mieczysław, ed., Stosunki Polski z sąsiadami w pierwszej dekadzie XXI wieku. 69-112, Wydawnictwo Uniwersytetu Śląskiego, Katowice. 
Leifer, Michael (1999): Indonesia's Encounters with China and The Dilemma's of Engagement, in Johnston, Alastair I. - Ross, Robert S., ed., Engaging China: The Management of an Emerging Power. 89-110, Routledge, New York.

Lobell, Steven E. (2009): Threat assessment, the state, and foreign policy: a neoclassical realist model, in Lobell, Steven E. - Ripsman, Norrin M. - Taliaferro, Jeffrey W., eds., Neoclassical Realism, the State, and Foreign Policy. 42-74, Cambridge University Press, Cambridge.

Lobell, Steven E. - Jesse, Neal G. - Williams, Kristen P. (2015): Why do secondary states choose to support, follow or challenge? International Politics 52: 146-162.

Longhurst, Kerry - Zaborowski, Marcin (2007): The New Atlanticist: Poland's Foreign and Security Policy Priorities, Blackwell Publishing Ltd., London.

Mal'gin, Artjom (2011): Rossiya i Pol'sha: skvoz' prizmu 'Vostochnoi Politiki' Evrosoyuza'. Vostochnaya Evropa Perspektivy 2: 6-19.

Mares, David R. (1988): Middle Powers under Regional Hegemony: To Challenge or Acquiesce in Hegemonic Enforcement. International Studies Quarterly 32(4): 453-471.

Meller, Stefan (2006) Informacja Ministra Spraw Zagranicznych o zadaniach polskiej polityce zagranicznej, przedstawiona na 10 posiedzeniu Sejmu RP V Kadencji', 15 February: available at: https://www.msz.gov.pl/resource/a9903f58-ddbb-4bc0-ba49-ee81c688d690:JCR (19 June 2020).

Narizny, Kevin (2017): On Systemic Paradigms and Domestic Politics. A Critique of the Newest Realism. International Security 42(2): 155-190.

Patience, Allan (2014): Imagining middle powers. Australian Journal of International Affairs 68(2): 210-224.

Resnick, Evan (2001): Defining Engagement. Journal of International Affairs 54(2): 551-566.

Ripsman, Norrin M. (2009): Neoclassical realism and domestic interest groups, in Lobell, Steven E. - Ripsman, Norrin M. - Taliaferro, Jeffrey W., eds., Neoclassical Realism, the State, and Foreign Policy. 170-193, Cambridge University Press, Cambridge.

Ripsman, Norrin M. - Taliaferro, Jeffrey W. - Lobell, Steven E. (2016): Neoclassical Realist Theory of International Politics, Oxford University Press, New York.

Rose, Gideon (1998): Neoclassical Realism and Theories of Foreign Policy. World Politics 51(1): 144-172.

Schweller, Randall L. (1998): Deadly Imbalances: Tripolarity and Hitler's Strategy of World Conquest, Columbia University Press, New York.

Schweller, Randall L. (2003): The Progressiveness of Neoclassical Realism, in Elman, Colin - Elman, Miriam F., eds., Progress in International Relations Theory. Appraising the Field. 311-347, MIT Press, Cambridge - London.

Schweller, Randall L (2017): The Concept of Middle Power, in Cha, Victor D. - Dumond, Marie, eds., The Korean Pivot: South Korea as a Global Power. 3-9, Centre for Strategic and International Studies, Washington.

Sikorski, Radostaw (2018): Polska Może Być Lepsza, Znak, Kraków. 
Spero, Joshua B. (2009): Great Power Security Dilemmas for Pivotal Middle Power Bridging. Contemporary Security Policy 30(1): 147-171

Stolarczyk, Mieczysław (2016): Rosja w polityce zagranicznej Polski w latach 1992-2015. Wydawnictwo Uniwersytetu Śląskiego, Katowice.

Taliaferro, Jeffrey W. (2006): State Building for Future Wars: Neoclassical Realism and the Resource-Extractive State. Security Studies 15(3): 464-495.

Taras, Raymond (2014): Russia Resurgent, Russophobia in Decline? Polish Perceptions of Relations with the Russian Federation 2004-2012. Europe-Asia Studies 66(5): 710-734.

Waltz, Kenneth N. (1979/2010): Theory of International Politics, Waveland Press, Long Grove.

Wawrzyński, Patryk (2012): The Remembrance of the Katyń Massacre and the President Lech Kaczyński's concept of Polish-Russian Relations [2005-2010]. Polish Political Science Yearbook 41: 507-525.

Zakaria, Fareed (2020): The New China Scare. Why America Shouldn't Panic About Its Latest Challenger. Foreign Affairs 99(1): 52-69.

Zając, Justyna (2016): Poland's Security Policy: The West, Russia, and the Changing International Order. Palgrave Macmillan, London.

Zięba, Ryszard (2013): Polityka zagraniczna Polski w strefie euroatlantyckiej, Wydawnictwa Uniwersytetu Warszawskiego, Warsaw.

Żurawski vel Grajewski, Przemysław (2011): Strategia Federacji Rosyjskiej wobec państw basenu Morza Bałtyckiego. Analizy natolińskie 4(52): 1-62.

\section{Table 1: Interview table}

\begin{tabular}{|c|c|c|c|c|c|c|}
\hline Respondent & Status & Source & $\begin{array}{l}\text { Theoretical } \\
\text { Saturation }\end{array}$ & Form & Length & Record \\
\hline \multicolumn{7}{|c|}{ Yes } \\
\hline $\begin{array}{c}\text { MFA } \\
\text { employee } 1\end{array}$ & $\begin{array}{c}\text { Done } 2 \text { March 2018, } \\
\text { Warsaw }\end{array}$ & $\begin{array}{l}\text { Sample } \\
\text { frame }\end{array}$ & & $\begin{array}{c}\text { Semi- } \\
\text { structured }\end{array}$ & 1h 16 min & $\begin{array}{l}\text { Audio } \\
\text { record }\end{array}$ \\
\hline $\begin{array}{c}\text { MFA } \\
\text { employee } 2\end{array}$ & $\begin{array}{c}\text { Done } 12 \text { May 2018, } \\
\text { Warsaw }\end{array}$ & $\begin{array}{l}\text { Sample } \\
\text { frame }\end{array}$ & & $\begin{array}{c}\text { Semi- } \\
\text { structured }\end{array}$ & 1h 13 min & $\begin{array}{l}\text { Audio } \\
\text { record }\end{array}$ \\
\hline $\begin{array}{c}\text { MFA } \\
\text { employee } 3\end{array}$ & $\begin{array}{c}\text { Done } 3 \text { July 2018, } \\
\text { Warsaw }\end{array}$ & $\begin{array}{c}\text { MFA } \\
\text { employee } 2\end{array}$ & & $\begin{array}{c}\text { Semi- } \\
\text { structured }\end{array}$ & 1h 59 min & $\begin{array}{l}\text { Audio } \\
\text { record }\end{array}$ \\
\hline $\begin{array}{c}\text { MFA } \\
\text { employee } 4\end{array}$ & $\begin{array}{c}\text { Done } 23 \text { October } \\
\text { 2018, Warsaw }\end{array}$ & $\begin{array}{c}\text { MFA } \\
\text { employee } 3\end{array}$ & & $\begin{array}{c}\text { Semi- } \\
\text { structured }\end{array}$ & 1h $30 \mathrm{~min}$ & $\begin{array}{l}\text { Audio } \\
\text { record }\end{array}$ \\
\hline $\begin{array}{c}\text { MFA } \\
\text { employee } 5\end{array}$ & $\begin{array}{l}\text { Done } 12 \text { December } \\
\text { 2018, Warsaw }\end{array}$ & $\begin{array}{c}\text { MFA } \\
\text { employee } 3\end{array}$ & & $\begin{array}{c}\text { Semi- } \\
\text { structured }\end{array}$ & 1h $15 \mathrm{~min}$ & $\begin{array}{l}\text { Audio } \\
\text { record }\end{array}$ \\
\hline $\begin{array}{c}\text { MFA } \\
\text { employee } 6\end{array}$ & $\begin{array}{c}\text { Refused } 5 \text { February } \\
2018\end{array}$ & $\begin{array}{l}\text { Member of } \\
\text { Parliament } 1\end{array}$ & & & & \\
\hline $\begin{array}{c}\text { MFA } \\
\text { employee } 7\end{array}$ & Did not reply & $\begin{array}{l}\text { Sample } \\
\text { frame }\end{array}$ & & & & \\
\hline
\end{tabular}




\begin{tabular}{|c|c|c|c|c|c|}
\hline $\begin{array}{c}\text { MFA } \\
\text { employee } 8\end{array}$ & $\begin{array}{l}\text { Refused } 26 \text { March } \\
2018\end{array}$ & $\begin{array}{l}\text { Sample } \\
\text { frame }\end{array}$ & & & \\
\hline $\begin{array}{l}\text { Member of } \\
\text { Parliament } 1\end{array}$ & $\begin{array}{l}\text { Done } 8 \text { February } \\
\text { 2018, Warsaw }\end{array}$ & $\begin{array}{l}\text { Sample } \\
\text { frame }\end{array}$ & $\begin{array}{c}\text { Semi- } \\
\text { structured }\end{array}$ & $30 \mathrm{~min}$ & $\begin{array}{l}\text { Audio } \\
\text { record }\end{array}$ \\
\hline $\begin{array}{l}\text { Member of } \\
\text { Parliament } 2\end{array}$ & $\begin{array}{c}\text { Done } 12 \text { December } \\
\text { 2018, Warsaw }\end{array}$ & $\begin{array}{c}\text { MFA } \\
\text { employee } 4\end{array}$ & $\begin{array}{c}\text { Semi- } \\
\text { structured }\end{array}$ & $45 \mathrm{~min}$ & $\begin{array}{l}\text { Audio } \\
\text { record }\end{array}$ \\
\hline $\begin{array}{l}\text { Government } \\
\text { MFA expert } 1\end{array}$ & $\begin{array}{c}\text { Done } 4 \text { July 2018, } \\
\text { Warsaw }\end{array}$ & $\begin{array}{c}\text { MFA } \\
\text { employee } 2\end{array}$ & $\begin{array}{c}\text { Semi- } \\
\text { structured }\end{array}$ & $47 \mathrm{~min}$ & $\begin{array}{l}\text { Audio } \\
\text { record }\end{array}$ \\
\hline $\begin{array}{l}\text { Government } \\
\text { MFA expert } 2\end{array}$ & $\begin{array}{c}\text { Refused } 5 \text { February } \\
2018\end{array}$ & $\begin{array}{l}\text { Member of } \\
\text { Parliament } 1\end{array}$ & & & \\
\hline $\begin{array}{l}\text { President's } \\
\text { chancellery's } \\
\text { employee } 1\end{array}$ & $\begin{array}{l}\text { Done } 19 \text { February } \\
\text { 2019, Warsaw }\end{array}$ & $\begin{array}{l}\text { Member of } \\
\text { Parliament } 2\end{array}$ & $\begin{array}{c}\text { Semi- } \\
\text { structured }\end{array}$ & 1h $25 \mathrm{~min}$ & $\begin{array}{l}\text { Audio } \\
\text { record }\end{array}$ \\
\hline $\begin{array}{l}\text { President's } \\
\text { chancellery's } \\
\text { employee } 2\end{array}$ & $\begin{array}{c}\text { Refused } 5 \text { February } \\
2018\end{array}$ & $\begin{array}{c}\text { MFA } \\
\text { employee } 1\end{array}$ & & & \\
\hline $\begin{array}{c}\text { Prime minister's } \\
\text { chancellery's } \\
\text { employee } 1\end{array}$ & $\begin{array}{l}\text { Refused } 5 \text { April } \\
2018\end{array}$ & $\begin{array}{l}\text { Sample } \\
\text { frame }\end{array}$ & & & \\
\hline $\begin{array}{l}\text { Prime minister's } \\
\text { chancellery's } \\
\text { employee } 2\end{array}$ & $\begin{array}{l}\text { Refused } 10 \text { April } \\
2018\end{array}$ & $\begin{array}{l}\text { Sample } \\
\text { frame }\end{array}$ & & & \\
\hline $\begin{array}{c}\text { Prime minister's } \\
\text { chancellery's } \\
\text { employee } 3\end{array}$ & Did not reply & $\begin{array}{l}\text { Sample } \\
\text { frame }\end{array}$ & & & \\
\hline
\end{tabular}

Marijuš Antonovič (Mariusz Antonowicz) is a PhD student and lecturer at Vilnius University's Institute of International Relations and Political Science. His research interests are mainly focused around Poland's foreign policy and theories of international relations. Vokiečiu st. 10, LT-01130, Vilnius, Lithuania. Email: marijus. antonovic@tspmi.vu.lt, tel. +37052514130,fax+37052514134. 